\title{
Control of Dental Plaque with Saptachada Kshara - A Case Series
}

\section{IJCRR}

Section: Healthcare

Sci. Journal Impact

Factor: 6.1 (2018)

ICV: 90.90 (2018)

(c) (i) (8)

Copyright@IJCRR

\section{Mira Krishnan M $^{1}$, K. Sivabalaji ${ }^{2}$, Ashwini BN ${ }^{3}$}

'PG Scholar, Department of Shalakyathantra (ENT, Dentistry and Ophthalmology), Amrita School of Ayurveda, Amrita Vishwa Vidyapeetham, Amritapuri, India; ${ }^{2}$ Assistant Professor, Department of Shalakyathantra (ENT, Dentistry and Ophthalmology), Amrita School of Ayurveda, Amrita Vishwa Vidyapeetham, Amritapuri, India; ${ }^{3}$ Associate Professor, Department of Shalakyathantra (ENT, Dentistry and Ophthalmology), Amrita School of Ayurveda, Amrita Vishwa Vidyapeetham, Amritapuri, India.

\section{ABSTRACT}

Introduction: Dental plaque is bacterial aggregations adhering to the tooth surface in the oral cavity. It may further result in gingivitis and periodontitis. Majority of the persons affected with plaque may not give much attention unless they experience some other symptoms like gingival bleeding, halitosis, dryness of mouth and sensitivity. Dental plaque may be compared with Dantasharkara, one of the dantaroga according to Ayurveda.

Aim: For the case series under reference, Dantasharkara Uddharana (removal of plaque) with shastra is told in Ayurveda. But the procedure is not standardized. So, the second line of treatment Kshara and Madhu pratisarana [rubbing] is adopted here.

Case Report: In the present clinical study, 30 patients were registered to have a complaint of Dantasharkara. Each case was observed for prevalence according to age, gender, socioeconomic status, occupation, diet pattern, frequency of cleaning teeth, tooth discolouration, tooth sensitivity, halitosis, dryness of mouth, plaque index and gingival bleeding index.

Result: 250 mg Saptachada kshara pratisarana and 100ml Tilayastimadhu ksheera gandusha daily once for 30 days showed significant reductions in tooth discolouration, sensitivity, halitosis, dryness of mouth, plaque and gingival bleeding indices, with an improvement of $83 \%, 100 \%, 93 \%, 97 \%, 95 \%$ and $95 \%$ respectively. Statistical analyses were performed with SPSS software and are clinically significant with $p<0.0001$.

Conclusion: Saptachada being a pratisaraniya kshara dravya is mentioned in kushtaghna mahakashaya and sa krimya Vrana chikitsa. Due to lekhana, chedana, bhedana pachana, vilayana and kapha vata shamaka karma, kshara becomes responsible for samprapti vighatana of danta sharkara. Saptachada kshara pratisarana is safe, effective and has proved to have better patient's tolerance.

Key Words: Dental Plaque, Oral Hygiene, Saptachada Kshara, Tilayastimadhu ksheera, Plaque Index

\section{INTRODUCTION}

Dental plaque results from colonization and growth of microorganisms on the surface of teeth, if not treated in time may exacerbate the condition leading to gingivitis, periodontal diseases and even tooth loss. India reports more than 10 million plaque related cases every year. Oral hygiene plays a major role in once healthy living. Effective treatment can control plaque and its progression. As per classic dantasharkara explained in mukharoga, it is due to improper oral hygiene by which the vitiated vata dry the Kapha and dantamala [The waste precipitations on teeth] and so the teeth appear with yellow or brown colored precipitations and halitosis. ${ }^{1}$ The treatment adopted in dantasharkara was Saptachada kshara pratisarana[rubbing].
Intolerance to hot and cold substances is the main side effect seen after scaling and root-planning. Acharyas had mentioned, Danta Harsha chikitsa (treatment for the sensitivity of tooth) after Dantasharkara udharana (removal of dental plaque). Milk boiled with Tila and Yastimadhu choorna was given for gandoosha. ${ }^{2}$ Saptachada (Alstonia scholaris) is mentioned by vagbhatta in aragwadiya Gana(cleanses bad wounds), krimija Vrana (disinfect wound)and in mukhapaka(mouth ulcer). Kshara alleviates three dosas by Lekhanam (scarifying), Chedana (excision) and Bhedana (incision), vilayana (liquefies), shodana (cleanses) and ropa$n a$ (healing) property. ${ }^{3}$ Madhu is mentioned in Sandhaneeya and Sthapana mahakashaya. ${ }^{4}$ It alleviates three doshas having Vrana shodana, Sandhana, Ropana and krimihara prop-

\section{Corresponding Author:}

Dr. Mira Krishnan M, Department of Shalakya Tantra, Amrita School of Ayurveda, Amritapuri, Kollam, India. Phone: 7736853957; Email: vishmira@gmail.com

ISSN: 2231-2196 (Print)

Received: 19.07.2020
ISSN: $0975-5241$ (Online)

Revised: 10.09 .2020
Accepted: 18.10 .2020
Published: 12.11 .2020 
erties. Honey migrating through the epithelium of the gingival crevice has got both bactericidal and rinsing function. ${ }^{5}$

Tila (Sesamum indicum) is snigdho vrane lepana (beneficial for the wound as an external paste) and dantya (wholesome for teeth). ${ }^{6}$ Yastimadhu (Glycyrrhiza glabra) comes under sandhaneeya and shonitha sthapanagana ie herbs that help in healing and checking of bleeding. ${ }^{7}$ Tila and Yastimadhu rich in calcium preserve the root around tooth and gums. Gandusha helps in treating several health conditions and nourishes the sense organs. It stimulates taste perception and increases salivation. Saliva contains Ptylin and lysosomes, which acts as bacteriosidal.

\section{MATERIALS AND METHODS}

The study was conducted at Amrita School of Ayurveda, Amritapuri. Thirty patients reporting at the outpatient department of Shalakya and diagnosed clinically as the case of dental plaque with chronicity less than 5yrs along with tooth discolouration, sensitivity, halitosis and dryness of mouth were included in the study. Patients with presence of extensive caries and fracture of teeth, use of orthodontic appliances in previous 6 months, continuous usage of mouthwashes in previous 6 months, history of allergy to dentifrices or history of any uncontrolled systemic diseases were excluded. The study procedure was explained to thirty patients participating in the study.

Scores of subjective criteria, plaque index and gingival bleeding index were recorded on the $1^{\text {st }}$ and $30^{\text {th }}$ day of treatment and were reassessed during the four follow-ups. The examinations were done by the investigator well trained with the procedure using mouth mirror and William's probe, inadequate illumination. Parameters used were Quigley and Hein plaque index and Loe and Silness gingival bleeding index.

Statistical significance of mean scores between before and after treatment were assessed using the paired t-test. Subjective parameters were assessed using the Wilcoxon sign rank test. Statistical analyses were performed with SPSS software for Windows.

\section{Study design}

The study was designed as an open-label clinical trial and the guidelines of the CONSORT statement were followed. The study protocol was reviewed and approved by the Institutional Ethics Board Committee on research. Written informed consent in agreement with the Declaration of Helsinki was obtained from all enrolled individuals. Clinical Trial Registry was also done. 30 Participants who were fulfilling the criteria were selected for the clinical study and were provided with enough their assigned products.

\section{Subjective parameters}

All selected participants were observed before and after treatment visit on the $30^{\text {th }}$ day and as follow-ups on the $45^{\text {th }}$ day, $60^{\text {th }}$ day, $75^{\text {th }}$ day and $90^{\text {th }}$ day.

These consultations involved the assessment of

- Tooth discolouration

- Tooth sensitivity

- Halitosis

- Dryness of mouth. [ Table no: 1]

Table 1: showing the Grading system for subjective parameters

\begin{tabular}{ll} 
Criteria & Score \\
Tooth discolouration & Present -1, Absent -o \\
Teeth sensitivity & $\begin{array}{l}\text { Acceptable-o, Tolerable -1, Intoler- } \\
\text { able -2 }\end{array}$ \\
Halitosis & Present -1, Absent -o. \\
Dryness of mouth & Present -1, Absent -o. \\
\hline
\end{tabular}

Patients with tooth discolouration, tolerable tooth sensitivity, halitosis and dryness of mouth were given score 1 . The absence of these subjective criteria was given score 0 . Patients with intolerable tooth sensitivity were given score 2 .

\section{Objective parameters}

- The Plaque score was assessed using a standard scale called the Turesky Modification of the Quigley Hein Plaque Index and scored from 0 to 3 . This index measures the thickness of plaque on the gingival one-third.

- Gingivitis was assessed using Gingival bleeding index on interdental space. Bleeding response to the horizontal pressure applied in the interdental area by a dental probe was recorded. After $30 \mathrm{~s}$, bleeding at each gingival unit was recorded. Any change in gingival colour and oedema was noted.

- Used on all teeth (28, so wisdom teeth are excluded) or selected 6 teeth.

- No substitution of the missing tooth. Used on all 4 surfaces (M, O, D, L). [ Table no: 2]

Table 2: showing the grading system for plaque index Criteria Scores No plaque

A film of plaque adhering to the free gingival margin $\quad 1$ and adjacent area of the tooth.

Moderate accumulation of soft deposit within the gingival pocket, or the tooth and gingival margin which can be seen with the naked eye.

The abundance of soft matter within the gingival pocket and/or on the tooth and gingival margin. 
On oral examination, a tooth with no plaque was given score 0 and those with mild plaque adhering to the free gingival margin and adjacent area of the tooth were given score 1 . Moderate accumulation of plaque within the gingival pocket, or the tooth and gingival margin which can be seen with the naked eye were given score 2 . The abundance of soft matter within the gingival pocket and/or on the tooth and gingival margin was given score 3 .

\section{Therapeutic interventions}

Patients were administered with $250 \mathrm{mg}$ of Saptachada kshara along with 4 drops of Madhu for Danta Pratisarana (dental rubbing) in a circular pattern followed by $100 \mathrm{ml}$ of Tila yastimadhu ksheera gandoosha (rinsing) for 30 consecutive days. (Table 3). The patient's tooth discolouration, sensitivity, halitosis, dryness of mouth, plaque index and gingival bleeding index were assessed before and after treatment and during the four follow-ups done in every 15 days for the next 2 months. The pre and post photographs were also taken.

Table 4: Shows the ranking of tooth discolouration

\begin{tabular}{|c|c|c|c|c|c|}
\hline Tooth discolouration ranks & N rank & Mean rank & Sum of ranks & $\mathrm{Z}$ value & $\begin{array}{l}\text { Asymp. Sig. } \\
\text { (2-tailed) }\end{array}$ \\
\hline $\begin{array}{l}\text { Tooth_discoloration_AT - Negative rank } \\
\text { Tooth_discoloration_BT Positive rank } \\
\text { Ties } \\
\text { Total }\end{array}$ & $\begin{array}{l}25^{\mathrm{a}} \\
\mathrm{O}^{\mathrm{b}} \\
5^{\mathrm{c}} \\
30\end{array}$ & $\begin{array}{c}13.00 \\
.00\end{array}$ & $\begin{array}{l}325.00 \\
.00\end{array}$ & $-5.000^{b}$ & 0.001 \\
\hline $\begin{array}{l}\text { Tooth_discoloration_FU1 - Negative rank } \\
\text { Tooth_discoloration_BT Positive rank } \\
\text { Ties } \\
\text { Total }\end{array}$ & $\begin{array}{l}25^{\mathrm{d}} \\
\mathrm{O}^{\mathrm{e}} \\
5^{\mathrm{f}} \\
30\end{array}$ & $\begin{array}{l}13.00 \\
.00\end{array}$ & $\begin{array}{l}325.00 \\
.00\end{array}$ & $-5.000^{b}$ & 0.001 \\
\hline $\begin{array}{l}\text { Tooth_discoloration_FU2 - Negative rank } \\
\text { Tooth_discoloration_BT Positive rank } \\
\text { Ties } \\
\text { Total }\end{array}$ & $\begin{array}{c}25^{\mathrm{g}} \\
\mathrm{O}^{\mathrm{h}} \\
5^{\mathrm{i}} \\
30\end{array}$ & $\begin{array}{l}13.00 \\
.00\end{array}$ & $\begin{array}{l}325.00 \\
.00\end{array}$ & $-5.000^{\mathrm{b}}$ & 0.001 \\
\hline $\begin{array}{l}\text { Tooth_discoloration_FU3 - Negative rank } \\
\text { Tooth_discoloration_BT Positive rank } \\
\text { Ties } \\
\text { Total }\end{array}$ & $\begin{array}{c}25^{\mathrm{j}} \\
\mathrm{O}^{\mathrm{k}} \\
5^{1} \\
30\end{array}$ & $\begin{array}{l}13.00 \\
.00\end{array}$ & $\begin{array}{l}325.00 \\
.00\end{array}$ & $-5.000^{b}$ & 0.001 \\
\hline $\begin{array}{l}\text { Tooth_discoloration_FU4 - Negative rank } \\
\text { Tooth_discoloration_BT Positive rank } \\
\text { Ties } \\
\text { Total }\end{array}$ & $\begin{array}{l}25 \mathrm{~m} \\
0^{\mathrm{n}} \\
5^{\mathrm{o}} \\
30\end{array}$ & $\begin{array}{l}13.00 \\
.00\end{array}$ & $\begin{array}{c}325.00 \\
.00\end{array}$ & $-5.000^{b}$ & 0.001 \\
\hline
\end{tabular}

Table 3: Shows the therapeutic intervention

\begin{tabular}{llcc} 
Procedure & Medicine & Dose & Duration \\
Pratisarana & $\begin{array}{l}\text { Saptachada kshara }(2 \\
\text { min) }\end{array}$ & $250 \mathrm{mg}$ & 30 days \\
Gandusha & $\begin{array}{l}\text { Tila yastimadhu } \\
\text { ksheera }(5 \mathrm{~min})\end{array}$ & $\mathbf{1 0 0 \mathrm { ml }}$ & 30 days \\
\hline
\end{tabular}

\section{RESULTS}

Of the 33 participants enrolled in the study, three of them were considered dropped out due to an irregular visit to the hospital for follow-up.

Wilcoxon sign rank test showed a reduction in tooth discolouration, sensitivity, halitosis and dryness of mouth between BT and AT, follow-up 1, follow-up 2, follow-up 3, and follow-up 4, which is highly significant at all stages $\mathrm{P}<0.0001$ [Bonferroni Correction]. In subjective criteria, there is an improvement of $83 \%, 100 \%, 93 \%$ and $97 \%$ respectively. [Table no: $4,5,6,7]$.
Wilcoxon sign rank test showed reduction in tooth discoloration between BT and AT, follow-up 1, follow-up 2, follow-up 3 , and follow-up 4 in subjects, which is highly significant at all stages $\mathrm{P}<0.0001$ [Bonferroni Correction]. Above table makes it clear that 25 patients got reduction in tooth discoloration after treatment and 5 patients had the symptom persisted throughout the follow-up period. 
Table 5: Shows ranking of tooth sensitivity

\begin{tabular}{|c|c|c|c|c|c|}
\hline Tooth sensitivity ranks & $\mathrm{N}$ rank & $\begin{array}{c}\text { Mean } \\
\text { rank }\end{array}$ & $\begin{array}{l}\text { Sum of } \\
\text { ranks }\end{array}$ & $\mathrm{Z}$ value & $\begin{array}{l}\text { Asymp. Sig. } \\
\text { (2-tailed) }\end{array}$ \\
\hline $\begin{array}{l}\text { Tooth_sensitivity_AT - Negative rank Tooth_sensitiv- } \\
\text { ity_BT Positive rank } \\
\text { Ties } \\
\text { Total }\end{array}$ & $\begin{array}{l}30^{\mathrm{a}} \\
\mathrm{O}^{\mathrm{b}} \\
\mathrm{O}^{\mathrm{c}} \\
30\end{array}$ & $\begin{array}{c}15.50 \\
.00\end{array}$ & $\begin{array}{l}465.00 \\
.00\end{array}$ & $-5.069^{b}$ & 0.001 \\
\hline $\begin{array}{l}\text { Tooth_sensitivity_FU1 -Negative rank Tooth_sensitivity } \\
\text { _BT Positive rank } \\
\text { Ties } \\
\text { Total }\end{array}$ & $\begin{array}{c}30^{d} \\
0^{e} \\
0^{f} \\
30\end{array}$ & $\begin{array}{l}15.50 \\
.00\end{array}$ & $\begin{array}{l}465.00 \\
.00\end{array}$ & $-5.069^{b}$ & 0.001 \\
\hline $\begin{array}{l}\text { Tooth_sensitivity_FU2 - Negative rank Tooth_sensitivity } \\
\text { _BT Positive rank } \\
\text { Ties } \\
\text { Total }\end{array}$ & $\begin{array}{c}30^{\mathrm{g}} \\
\mathrm{o}^{\mathrm{h}} \\
5^{\mathrm{i}} \\
30\end{array}$ & $\begin{array}{l}15.50 \\
.00\end{array}$ & $\begin{array}{l}465.00 \\
.00\end{array}$ & $-5.069^{b}$ & 0.001 \\
\hline $\begin{array}{l}\text { Tooth_sensitivity_FU } 3 \text { - Negative rank Tooth_sensitiv- } \\
\text { ity n_BT Positive rank } \\
\text { Ties } \\
\text { Total }\end{array}$ & $\begin{array}{c}30^{j} \\
0^{k} \\
5^{1} \\
30\end{array}$ & $\begin{array}{c}15.50 \\
.00\end{array}$ & $\begin{array}{l}465.00 \\
.00\end{array}$ & $-5.069^{b}$ & 0.001 \\
\hline $\begin{array}{l}\text { Tooth_sensitivity_FU4 }- \text { Negative rank Tooth_sensitiv- } \\
\text { ity_BT Positive rank } \\
\text { Ties } \\
\text { Total }\end{array}$ & $\begin{array}{c}30^{g} \\
0^{k} \\
5^{1} \\
30\end{array}$ & $\begin{array}{l}15.50 \\
.00\end{array}$ & $\begin{array}{l}465.00 \\
.00\end{array}$ & $-5.069^{b}$ & 0.001 \\
\hline
\end{tabular}

Wilcoxon sign rank test showed a reduction in the feeling of tooth sensitivity between BT and AT, follow-up 1, follow-up 2, follow-up 3, and follow-up 4 in subjects which is highly significant at all stages $\mathrm{P}<0.0001$ [Bonferroni Correction]. From the table, it is clear that 30 patients had relief and it was sustained throughout all follow-ups.

Table 6: Shows the ranking of Halitosis

\begin{tabular}{|c|c|c|c|c|c|}
\hline Halitosis ranks & $\mathbf{N}$ rank & Mean rank & Sum of ranks & $\mathrm{Z}$ value & $\begin{array}{l}\text { Asymp. Sig. } \\
\text { (2-tailed) }\end{array}$ \\
\hline Halitosis_AT - Negative rank & $28^{\mathrm{a}}$ & 14.50 & 406.00 & $-5.292^{b}$ & 0.001 \\
\hline Halitosis_BT_Positive rank & $\mathrm{o}^{\mathrm{b}}$ & .00 & .00 & & \\
\hline Ties & $2^{c}$ & & & & \\
\hline Total & 30 & & & & \\
\hline Halitosis_FU1 - Negative rank & $28^{\mathrm{d}}$ & 14.50 & 406.00 & $-5.292^{\mathrm{b}}$ & 0.001 \\
\hline Halitosis_BT Positive rank & $\mathrm{O}^{\mathrm{e}}$ & .00 & .00 & & \\
\hline Ties & $2^{\mathrm{f}}$ & & & & \\
\hline Total & 30 & & & & \\
\hline Halitosis_FU2 - Negative rank & $25^{\mathrm{g}}$ & 14.50 & 406.00 & $-5.292^{b}$ & 0.001 \\
\hline Halitosis_BT_Positive rank & $\mathrm{o}^{\mathrm{k}}$ & .00 & .00 & & \\
\hline Ties & $5^{\mathrm{i}}$ & & & & \\
\hline Total & 30 & & & & \\
\hline Halitosis_FU3 - Negative rank & $25^{\mathrm{g}}$ & 14.50 & 406.00 & $-5.292^{b}$ & 0.001 \\
\hline Halitosis_BT Positive rank & $\mathrm{o}^{\mathrm{k}}$ & .00 & .00 & & \\
\hline Ties & $5^{i}$ & & & & \\
\hline Total & 30 & & & & \\
\hline Halitosis_FU4 - Negative rank & $25^{\mathrm{g}}$ & 14.50 & 406.00 & $-5.292^{b}$ & 0.001 \\
\hline Halitosis_BT Positive rank & $\mathrm{o}^{\mathrm{k}}$ & .00 & .00 & & \\
\hline Ties & $5^{i}$ & & & & \\
\hline Total & 30 & & & & \\
\hline
\end{tabular}


Wilcoxon sign rank test showed a reduction in tooth discolouration between BT and AT, follow-up 1, follow-up 2, follow-up 3, and follow-up 4 in subjects, which is highly significant at all stages $\mathrm{P}<0.0001$ [Bonferroni Correc- tion]. Above table makes it clear that 28 patients got a reduction in tooth discolouration after treatment and 2 patients had the symptom persisted throughout the followup period.

Table 7: Shows the ranking of dryness of mouth

\begin{tabular}{|c|c|c|c|c|c|}
\hline Dryness of mouth ranks & N rank & $\begin{array}{c}\text { Mean } \\
\text { rank }\end{array}$ & $\begin{array}{l}\text { Sum of } \\
\text { ranks }\end{array}$ & $\mathrm{Z}$ value & $\begin{array}{l}\text { Asymp. Sig. } \\
\text { (2-tailed) }\end{array}$ \\
\hline $\begin{array}{l}\text { Dryness_of_mouthAT - Negative rank Dryness_of_mouth- } \\
\text { BT Positive rank } \\
\text { Ties } \\
\text { Total }\end{array}$ & $\begin{array}{l}29^{\mathrm{a}} \\
0^{\mathrm{b}} \\
1^{\mathrm{c}} \\
30\end{array}$ & $\begin{array}{l}15.00 \\
.00\end{array}$ & $\begin{array}{l}435.00 \\
.00\end{array}$ & $-5 \cdot 385^{b}$ & .0 .001 \\
\hline $\begin{array}{l}\text { Dryness_of_mouth_FU1 - Negative rank Dryness_of_- } \\
\text { mouth_BT Positive rank } \\
\text { Ties } \\
\text { Total }\end{array}$ & $\begin{array}{c}29^{\mathrm{d}} \\
\mathrm{O}^{\mathrm{e}} \\
1^{\mathrm{f}} \\
30\end{array}$ & $\begin{array}{l}15.00 \\
.00\end{array}$ & $\begin{array}{l}435.00 \\
.00\end{array}$ & $-5 \cdot 385^{b}$ & 0.001 \\
\hline $\begin{array}{l}\text { Dryness_of_mouth_FU2 - Negative rank Dryness_of_ } \\
\text { mouth_BT Positive rank } \\
\text { Ties } \\
\text { Total }\end{array}$ & $\begin{array}{c}29^{g} \\
0^{h} \\
1^{i} \\
30\end{array}$ & $\begin{array}{l}15.00 \\
.00\end{array}$ & $\begin{array}{c}435.00 \\
.00\end{array}$ & $-5 \cdot 385^{b}$ & 0.001 \\
\hline $\begin{array}{l}\text { Dryness_of_mouth_FU3 - Negative rank Dryness_of_ } \\
\text { mouth_BT Positive rank } \\
\text { Ties } \\
\text { Total }\end{array}$ & $\begin{array}{c}29^{j} \\
0^{k} \\
1^{1} \\
30\end{array}$ & $\begin{array}{l}15.00 \\
.00\end{array}$ & $\begin{array}{l}435.00 \\
.00\end{array}$ & $-5.385^{b}$ & 0.001 \\
\hline $\begin{array}{l}\text { Dryness_of_mouth_FU4 - Negative rank Dryness_of_ } \\
\text { mouth_BT Positive rank } \\
\text { Ties } \\
\text { Total }\end{array}$ & $\begin{array}{l}29^{\mathrm{m}} \\
0^{\mathrm{n}} \\
1^{\mathrm{o}} \\
30\end{array}$ & $\begin{array}{l}15.00 \\
.00\end{array}$ & $\begin{array}{l}435.00 \\
.00\end{array}$ & $-5 \cdot 385^{b}$ & 0.001 \\
\hline
\end{tabular}

Wilcoxon sign rank test showed a reduction in tooth discolouration between BT and AT, follow-up 1, follow-up 2, follow-up 3, and follow-up 4 in subjects, which is highly significant at all stages $\mathrm{P}<0.0001$ [Bonferroni Correction]. Above table shows 29 patients got a reduction in tooth discolouration after treatment and 1 patient had the symptom persisted throughout the follow-up.

\section{RESULTS ON OBJECTIVE PARAMETERS}

Paired T-test was performed to evaluate the significant difference in the mean value of Plaque index and Gingival bleeding index. [Table no:8 and 9]

Table 8: Shows the ranking of Plaque index

\begin{tabular}{|c|c|c|c|c|c|c|c|c|c|}
\hline Parameters & $\begin{array}{c}\text { BT } \\
\text { mean } \\
\text { score }\end{array}$ & $\begin{array}{c}\text { AT } \\
\text { Mean } \\
\text { score }\end{array}$ & Mean & $\%$ of Improvement & SD & SE & t value & df & Sig. (2-tailed) \\
\hline $\begin{array}{l}\text { Plaque_Index_BT } \\
\text { Plaque_index_AT }\end{array}$ & 2.00 & .1667 & 1.83 & $95 \%$ & 0.38 & 0.06 & 26.5 & 29 & 0.0001 \\
\hline $\begin{array}{l}\text { Plaque_index_BT } \\
\text { Plaque_Index_FU1 }\end{array}$ & 2.00 & .1667 & 1.83 & $95 \%$ & 0.38 & 0.06 & 26.5 & 29 & 0.0001 \\
\hline $\begin{array}{l}\text { Plaque_index_BT } \\
\text { Plaque_Index_FU2 }\end{array}$ & 2.00 & .1667 & 1.83 & $95 \%$ & 0.38 & 0.06 & 26.5 & 29 & 0.0001 \\
\hline $\begin{array}{l}\text { Plaque_index_BT } \\
\text { Plaque_Index_FU3 }\end{array}$ & 2.00 & .1667 & 1.83 & $95 \%$ & 0.38 & 0.06 & 26.5 & 29 & 0.0001 \\
\hline $\begin{array}{l}\text { Plaque_index_BT } \\
\text { Plaque_Index_FU4 }\end{array}$ & 2.00 & .1667 & 1.83 & $95 \%$ & 0.38 & 0.06 & 26.5 & 29 & 0.0001 \\
\hline
\end{tabular}


Paired T-test was performed to evaluate the significant difference in the mean value of the Plaque Index. It was observed that there is a significant difference in mean values of before (2.00) and after treatment $(0.1667)$ and it was main- tained during follow-up 1, follow-up 2, follow-up 3, and follow-up 4 . The result was statistically highly significant with $\mathrm{p}<0.0001$.

Table 9: Shows ranking of Gingival Bleeding index

\begin{tabular}{|c|c|c|c|c|c|c|c|c|c|}
\hline Parameters & $\begin{array}{c}\text { BT } \\
\text { mean } \\
\text { score }\end{array}$ & $\begin{array}{c}\text { AT } \\
\text { Mean } \\
\text { Score }\end{array}$ & Mean & $\begin{array}{c}\% \text { of Im- } \\
\text { provement }\end{array}$ & SD & SE & t value & df & $\begin{array}{c}\text { Sig. } \\
\text { (2-tailed) }\end{array}$ \\
\hline $\begin{array}{l}\text { G.B_Index_BT } \\
\text { G.B_Index_AT }\end{array}$ & 2.10 & .133 & 1.96 & $95 \%$ & 0.67 & 0.12 & 16.1 & 29 & 0.0001 \\
\hline $\begin{array}{l}\text { G.B_Index_BT } \\
\text { G.B_Index_FU1 }\end{array}$ & 2.10 & .133 & 1.96 & $95 \%$ & 0.67 & 0.12 & 16.1 & 29 & 0.0001 \\
\hline $\begin{array}{l}\text { G.B_Index_BT } \\
\text { G.B_Index_FU2 }\end{array}$ & 2.10 & .133 & 1.96 & $95 \%$ & 0.67 & 0.12 & 16.1 & 29 & 0.0001 \\
\hline $\begin{array}{l}\text { G.B_Index_BT } \\
\text { G.B_Index_FU3 }\end{array}$ & 2.10 & .133 & 1.96 & $95 \%$ & 0.67 & 0.12 & 16.1 & 29 & 0.0001 \\
\hline $\begin{array}{l}\text { G.B_Index_BT } \\
\text { G.B_Index_FU4 }\end{array}$ & 2.10 & .133 & 1.96 & $95 \%$ & 0.67 & 0.12 & 16.1 & 29 & 0.0001 \\
\hline
\end{tabular}

Paired T-test was performed to evaluate the significant difference in the mean value of Gingival Bleeding Index. It was observed that there is a significant difference in mean values of before (2.10) and after treatment (0.133) and it was maintained during follow-up 1, follow-up 2, follow-up 3, and follow-up 4. The result was statistically highly significant with $\mathrm{p}<0.0001$.

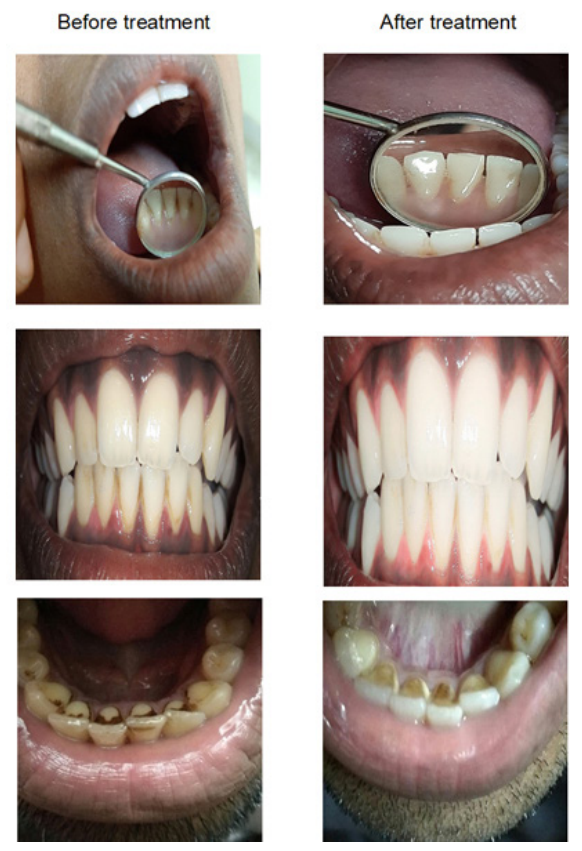

Figure 1: Comparison of before and after treatment.

\section{Overall effect of therapy Improvement}

The effect of Saptachada kshara pratisarana treatment was assessed for follow-ups done every 15 days for the next 2 months. [Table no. 10]

\section{Table 1o: Overall effect of therapy Improvement}

\begin{tabular}{lc} 
Improvement & Percentage of Improvement \\
$\begin{array}{l}\text { Complete improvement in } \\
\text { Tooth sensitivity }\end{array}$ & $100 \%$ \\
Marked improvement in & \\
Tooth discolouration, & $83 \%$ \\
Halitosis & $93 \%$ \\
Dryness of mouth & $97 \%$ \\
\hline
\end{tabular}

All the 30 patients got improvement in sensitivity, 25 patients got improvement in discolouration, 28 patients got improvement in halitosis and 29 patients got improvement in dryness of the mouth. The use of Saptachada kshara is safe, effective and proved to have better patient's tolerance. The alternate hypothesis is accepted i.e. Saptachada kshara pratisarana is effective in the management of dental plaque.

\section{DISCUSSION}

Classics explains this condition as dantasharkara in mukharoga. Due to improper oral hygiene, there is the accumulation of annamala (food debris) on the teeth or Kapha 
dehydrated by Vata, adhering to teeth becoming hard it takes the shape of thick adherence like the sand gravels and emitting a bad odour. If not treated in time it leads to dantanam gunahari (destroys the natural qualities of the tooth). Dental plaque is bacterial aggregations adhering to the tooth surface in the oral cavity. It is a sticky colorless deposit at first, but when it forms tartar it is often brown or pale yellow. The build-up of dental plaque can give rise to gingivitis and periodontitis. By considering the nidana (causative factors) and Lakshana (symptoms) of dantasharkara, the therapies are adapted. Standard treatment techniques in contemporary science are Scaling, root planning and flossing. ${ }^{5}$

For the case under reference, dantasharkara uddharana (removal of plaque) with shastra is told in Ayurveda. But the procedure is not standardized. So, the second line of treatment kshara and Madhu pratisarana [rubbing] is adopted here. In the present study, it was observed that majority ie. $46 \%$ of patients were belonging to the age group between $20-25 y$ rs and $63 \%$ of participants were females. The educational status of the present study reveals that $30 \%$ of the patients are students, whereas $17 \%$ of the patients belonged to the house-wife category and businessmen. $77 \%$ of the participants were having the habit of brushing only once daily.

Kshara due to pachana, vilayana and kapha vata karma becomes responsible for samprapti vighatana of danta sharkara. As vitiation of vata kapha dosha is responsible for the disease. When the kshara is applied over a particular place there will be erosion of the dead tissues and the healthy tissues get exposed, thereby initiating healing. Here kshara was mixed with madhu as it is yogavahi, and promotes sandana, shodana and ropana gunas. Kshara to fulfil the definition of shodana dravya can remove mala from body ${ }^{8}$. Lekhana,chedana and bhedanaguna of kshara helps to disintegrate the plaque from its site thereby reducing plaque index. It has vrana ropaka and mukha dourgandhyahara property, which helps in the reduction of sensitivity and halitosis.

Sensitive teeth are typically the result of worn tooth enamel or exposed tooth roots. So, the wound healing activity of Saptachada and Madhu helps in reducing sensitivity. Tila is Snigdho vrane lepane and has an antibacterial effect. Polyunsaturated fatty acid in Tila reduces free radical injury occurring in the oral cavity and thus helps to reduce plaqueinduced gingivitis. Tila and Yastimadhu used in gandusha are rich in calcium and it preserves the root around tooth and gums ${ }^{9}$. They also help slough off plaque while helping build tooth enamel. Gandusha generates antioxidants which damage the cell wall of microorganisms and kill them. This will attract the lipid layer of bacterial cell membranes, and cause it to stick or get attracted, and pulled to the oil. During gandusha, the oil gets emulsified and surface area of the oil gets increased. ${ }^{10}$ The process of emulsification of oil begins upon 5 min of gandusha. This liquid will coat the teeth and gingiva and inhibits bacterial co-aggregation and plaque formation. ${ }^{11}$ Thus, plaque building bacteria responsible for dental caries, gingivitis, periodontitis and bad breath are removed from the oral cavity. The salivary flow rate may be a contributing factor in the incidence of caries, and reduction in salivary output may result in rapid deterioration in oral health. ${ }^{12}$ Normal salivary $\mathrm{pH}$ is 6.2 to 7.6 . Being alkaline, kshara pratisarana (Potential of Hydrogen 8.4) also helps to make salivary Potential of Hydrogen in neutrancy. Gandusha is also of help to resolve symptoms of dry mouth and chapped lips.

Saptachada kshara's gradual but sustained chemical action removed the debris from the site and it helps in the formation of healthy granulation tissue thereby introducing a long healthy pattern in the depth of the tissue. ${ }^{13}$ Its antibacterial activity helps to control the infection as well as reduce the bacterial density which leads to the speedy recovery of the disease. $^{14}$

\section{CONCLUSION}

The clinical trial was conducted to see the effectiveness of Saptachada kshara in dental plaque. 250mg Saptachada kshara pratisarana, daily once for 30 days showed significant reductions in tooth discoloration, sensitivity, halitosis, dryness of mouth, plaque and gingival bleeding indices, which are statistically significant.

\section{ACKNOWLEDGEMENT}

We acknowledge the immense help received from the scholars whose articles are cited and included in references to this manuscript.

IEC Permission number and Date: IEC-AIMS-2018AYUR-242. Dated: 4.1.2019

\section{Patient Consent}

The patients voluntarily gave his/ her consent to have their case documented and published.

\section{Source of Support: Nil}

Conflict of Interest: None declared.

\section{REFERENCES}

1. Srikantha Murthy KR, editor. Varanasi: Krishnadas Academy. Astanga Hrdayam. 2000; 586.

2. Srikantha Murthy K.R, editor. Varanasi: Krishnadas Academy; Astanga Hrdayam; Uttara Sthāna 1997;200.

3. Srikantha Murthy KR, editor. Varanasi: Chaukhambha orientalia;Susruta, Sushruta samhita, Sutrasthana, 2012; 117. 
4. Abdalhamed AM, Zeedan GSG, Zeina HAAA. Isolation and identification of bacteria causing mastitis in small ruminants and their susceptibility to antibiotics, honey, essential oils, and their plant extracts. Vet World 2018;11(3):355-362.5.

5. VijayaKumari K, Nishteswar K. Wound healing activity of honey: A pilot study. AYU; 2012;33: 374-377.

6. Priya vrat Sharma, editor. Varanasi: Chaukhambha Krishnadas Academy, Susruta samhita, Sutra Sthāna, ${ }^{\text {nd }}$ Edition, 1997: 471.

7. Chandler RF. Liquorice more than just a flavor. Can Pharm J.1985;118:420-4.

8. Srikantha Murthy KR, editor. Varanasi: Chaukhambha orientalia;Susruta, Sushruta samhita, Sutrasthana, 2012;115

9. Kiran K, Asad.M. Wound healing activity of sesamum indicum seed and oil in rats. Indian J Exp Biol 2008;46(11):777-82.

10. Majdala weih AF, Massri M, Nasrallah GK, A comprehensive review on the anticancer properties and mechanism of action of sessamin, and lignan in sesame seeds. EurJ Pharmacol 2017:815:512-521.

11. Pengelley A. The constituents of medicinal plants, an introduction to the chemistry and therapeutics of herbal medicine. First south Asian edition, 2006.

12. Singh C. evaluation of invitro study of antioxidant and antibacterial activities of methanolic seed extract of Sessamum indicum. J Pharmacog Phytochem 2015:3(5):88.

13. Khyade MS, Vaikos NP. Phytochemical and antibacterial properties of leaves of Alstonia scholaris R. Br. Afr J Biotechnol 2009;8: 6434-6.

14. Arulmozhi S, Rasal VP, Sathiyanarayanan L, Ashok P. Screening of Alstonia scholaris Linn. R.Br. for wound healing activity. Opem 2007;7: 254-60. 